\title{
SVEIKATOS PRIEŽIŪROS PASLAUGŲ KOKYBĖS VERTINIMAS KARDIOLOGIJOS CENTRE: PACIENTŲ POŽIŪRIS
}

\author{
Aldona Mikaliūkštienè $\dot{2}^{2,3}$, Lina Baltokaité ${ }^{3}$, Danutė Kalibatiene் ${ }^{1,4}$, Natalja Jerdiakova ${ }^{2,3}$ \\ ${ }^{1}$ Vilniaus miesto klinikinè ligonine, ${ }^{2}$ Vilniaus universiteto Medicinos fakulteto \\ Sveikatos mokslu instituto Slaugos katedra, ${ }^{3}$ Vilniaus universiteto ligonine Santaros klinikos, \\ ${ }^{4}$ Vilniaus universiteto Medicinos fakulteto Klinikines medicinos institutas, \\ Vidaus ligu, šeimos medicinos ir onkologijos klinika
}

Raktažodžiai: sveikatos priežiūros paslaugų kokybė, paslaugų kokybės vertinimas, pacientų lūkesčiai, pacientų ìspūdžiai.

\begin{abstract}
Santrauka
Darbo tikslas: išanalizuoti sveikatos priežiūros paslaugų kokybę pacientų požiūriu Vilniaus miesto ligoninès kardiologijos centre.

Tyrimo medžiaga ir metodai. Anketinè apklausa. Imtis - 200 pacientų. Vertinti pacientų lūkesčiai ir įspūdžiai apie ligoninès kardiologijos centre teikiamas sveikatos priežiūros paslaugas.

Statistinè duomenų analizė atlikta naudojant kompiuterinès programos statistikos paketą „SPSS 13.0“ ir Microsoft Office Excel 2007 programą.

Rezultatai ir išvados. Apklaustieji aukštais balais vertino lūkesčius ligoninès atžvilgiu. Vyrų lūkesčiai materialinių vertybių, ligoninès patikimumo, darbuotojų jautrumo, pacientų saugumo ir darbuotojų empatijos atžvilgiu buvo mažesni nei moterų $(p<0,05)$. Apklaustųjų amžius reikšmingai teigiamai susijęs su lūkesčiais darbuotojų empatijos atžvilgiu ir visais įspūdžiais apie ligoninę. Aukštesnis išsilavinimas susijęs su mažesniais lūkesčiais ligoninès materialinių vertybių, patikimumo ir darbuotojų jautrumo atžvilgiu ir prastesniais įspūdžiais apie materialines vertybes ir ligoninès darbuotojų jautrumą. Nustatytos koreliacijos $(\mathrm{p}<0,01)$ tarp tiriamujjų lūkesčių ligoninès atžvilgiu ir ịspūdžių apie ligoninę, lūkesčiai buvo didesni nei įspūdžiai $(p=0,0001)$.
\end{abstract}

\section{Ivadas}

Daugelio Europos šaliu gyventojai, politikai, sveikatos priežiūros sistemos darbuotojai ir vadovai akcentuoja būtinybę gerinti sveikatos priežiūros paslaugų kokybę [1].
Sveikatos priežiūros kokybei didelị dèmesị skiria tarpvyriausybinès organizacijos: Europos Taryba, Europos Komisija, Pasaulio sveikatos organizacijos (PSO) Europos regioninis biuras bei tarptautinès nevyriausybinès organizacijos - Europos sveikatos priežiūros kokybès draugija, Europos kokybės organizacija, Europos kokybès vadybos fondas ir kt. [2, 3].

Vienas svarbiausių Lietuvos sveikatos apsaugos ministerijos (SAM) strateginių tikslų yra siekis, kad gyventojams būtų teikiamos kokybiškos, saugios ir prieinamos sveikatos priežiūros paslaugos [1]. Sveikatos priežiūros įstaigos siekia geriau patenkinti pacientų poreikius, išlaikyti esamus ir pritraukti naujus pacientus, išlikti ir vystytis [4-6]. Kokybiškos sveikatos paslaugos suteikia realias galimybes tenkinti pacientų poreikius, taupyti išteklius, skatinti darbuotojų atsakomybę, ugdyti žinias ir didinti kompetenciją [1].

Sveikatos paslaugų kokybės lygis - svarbus rodiklis, iš esmès atspindintis visuomenès sveikatos priežiūros kokybės lygị. Aukšta sveikatos paslaugų kokybė charakterizuoja sveikatos apsaugos valdymą kaip efektyvų, sistemingą, funkcionalų ir perspektyvų rinkoje procesą [7].

Paslaugų kokybės samprata formuojama tiek vartotojo, tiek teikèjo požiūriu, todèl svarbu, jog jų suvokiamas požiūris i kokybę sutaptų. Tik tokiu atveju paslaugų kokybė atitiks kiekvieno poreikius ir sąlygos abipusę naudą [8]. Kiekvienos sveikatos paslaugas teikiančios įstaigos vadovams svarbu žinoti, koks yra jų teikiamų paslaugų kokybès lygis. Nuo paslaugų kokybės lygio priklauso ne tik tos įstaigos pacientų pasitenkinimas, bet ir jos konkurencinis pranašumas, dažnai laikomas pagrindiniu sėkmingos veiklos garantu. Paslaugu kokybės vertinimas yra būtinas, jeigu įstaigų vadovai nori nenuvilti savo pacientų. Tik žinant teikiamų paslaugų kokybės lygị ir nuolat analizuojant rezultatus, galima kurti ir vykdyti strateginius planus, diegti kokybès vadybos sistemas, tobulinti veiklą bei didinti darbuotojų našumą $[8,9]$.

Orientacija ị pacientą - viena iš svarbiausių kokybiškos 
sveikatos priežiūros dimensijų [7]. Remiantis PSO teigimu, kiekvienas pacientas turi gauti tokias sveikatos priežiūros paslaugas, kurios užtikrintų optimaliausius sveikatos gerinimo rezultatus, atsižvelgiant į mokslo pasiekimus, paciento amžių, ligos diagnozę, reakcijas ị gydymą ir kt. Be to, visų rezultatų turi būti siekiama minimaliai išnaudojant ribotas priemones, maksimaliai sumažinant traumų, nepageidaujamų reiškinių ir komplikacijų riziką [10].

Darbo tikslas - ịvertinti sveikatos priežiūros paslaugų kokybę pacientų požiūriu Vilniaus miesto ligoninès kardiologijos centre.

\section{Tyrimo medžiaga ir metodai}

Tiriamųjų populiaciją sudare 200 pacientų, kurie tyrimo laikotarpiu gydėsi vienos iš Vilniaus miesto ligoninių kardiologijos centre. Taikyta anketine apklausa raštu. Paslaugų kokybei vertinti naudotas dviejų dalių klausimynas: pirmos dalies 15 anketos klausimų skirti pacientų lūkesčių ligoninès ir jos personalo atžvilgiu įvertinimui, antros dalies 15 klausimų skirti pacientų ịspūdžių konkrečiame skyriuje ịvertinimui. Lūkesčių ir ịspūdžių skalès sąlyginai dalinamos ị blokus po tris teiginius ( 5 blokai): klausimai apie ligoninès materialines vertybes; ligoninès patikimumą; ligoninès darbuotojų jautrumą; saugumą ir darbuotojų empatiją. Atsakymų variantai pateikti Likerto (Likert)

1 lentelè. Tiriamųų lūkesčiai ligoninès atžvilgiu.

\begin{tabular}{|l|l|l|l|}
\hline \multirow{2}{*}{ Lūkesčiai } & \multicolumn{3}{|c|}{ Lūkesčių vertinimas balais } \\
\cline { 2 - 4 } & Min & Max & vidurkis \pm SN \\
\hline Materialinės vertybės & 11 & 15 & $14,40 \pm 0,99$ \\
\hline Ligoninės patikimumas & 9 & 15 & $14,39 \pm 1,01$ \\
\hline Ligoninės darbuotojų jautrumas & 11 & 15 & $14,46 \pm 0,94$ \\
\hline Pacientų saugumas & 11 & 15 & $14,44 \pm 1,01$ \\
\hline Ligoninės darbuotojų empatija & 8 & 15 & $13,67 \pm 1,55$ \\
\hline
\end{tabular}

2 lentelè. Tiriamųjų lūkesčių ligoninès atžvilgiu palyginimas.

vid. sk. - vidurkiu skirtumas, $t$-Stjudento t kriterijus, $p$ - reikšmingumo lygmuo

\begin{tabular}{|l|c|c|c|c|c|}
\hline \multicolumn{2}{|l|}{ Lūkesčiai } & $\begin{array}{c}\text { Ligoninés } \\
\text { patikimu- } \\
\text { mas } \\
\text { (vid=14,39) }\end{array}$ & $\begin{array}{c}\text { Darbuo- } \\
\text { toju jau- } \\
\text { trumas } \\
\text { (vid=14,46) }\end{array}$ & $\begin{array}{c}\text { Pacientu } \\
\text { saugumas } \\
\text { (vid=14,44) }\end{array}$ & $\begin{array}{c}\text { Dar- } \\
\text { buotoju } \\
\text { empatija } \\
\text { (vid=13,67) }\end{array}$ \\
\hline Materialinès & vid. sk. & 0,01 & $-0,60$ & $-0,04$ & 0,73 \\
vertybès & $\mathrm{t}$ & 0,174 & $-1,014$ & $-0,634$ & 7,145 \\
(vid=14,40) & $\mathrm{p}$ & 0,862 & 0,312 & 0,527 & 0,0001 \\
\hline Ligoninès & vid. sk. & & $-0,07$ & $-0,05$ & 0,72 \\
patikimu- & $\mathrm{t}$ & & $-1,497$ & $-0,913$ & 7,741 \\
mas & $\mathrm{p}$ & & 0,136 & 0,362 & 0,0001 \\
(vid=14,39) & & & & & \\
\hline Darbuotojuc & vid. sk. & & & $-0,02$ & 0,79 \\
jautrumas & $\mathrm{t}$ & & & $-0,249$ & 8,293 \\
(vid=14,46) & $\mathrm{p}$ & & & 0,804 & 0,0001 \\
\hline Pacientuc & vid. sk. & & & & 0,77 \\
saugumas & $\mathrm{t}$ & & & & 9,004 \\
(vid=14,44) & $\mathrm{p}$ & & & & 0,0001 \\
\hline
\end{tabular}

skalès principu nuo „visiškai sutinku“ iki „visiškai nesutinku“. Apdorojant tyrimo duomenis atsakymas „,visiškai sutinku“ ivvertintas 5 balais, ,beveik sutinku“ -4 balais, ,nežinau“ - 3 balais, ,,beveik nesutinku“ -2 balais, ,visiškai nesutinku“ - 1 balu. Taigi, kiekvienas blokas galèjo turèti maksimalų 15 balų ir minimalų 3 balų ivvertinimą. Metodikos patikimumas patikrintas, pasitelkus Kronbacho (Cronbach) alfa koeficiento rodikli $(0,73)$.

Statistinè duomenu analizè atlikta naudojant kompiuterinès programos statistikos paketą „SPSS 13.0“ ir Microsoft Office Excel 2007 programą. Aprašomosios statistikos metodais apskaičiuotos ivvairių rodiklių skaitinès charakteristikos (vidurkiai, standartiniai nuokrypiai, minimalios ir maksimalios reikšmès, pasiskirstymo skaičiai (n), procentai). Stjudento (Student) t kriterijus priklausomoms imtims taikytas lyginant tiriamujų lūkesčių blokus tarpusavyje ir įspūdžių blokus tarpusavyje. Pirsono (Pearson) koreliacijos koeficientas (r) taikytas analizuojant ryšius tarp lūkesčių ligoninès atžvilgiu, įspūdžių apie ligoninę, demografinių rodiklių, paslaugų kokybės vertinimo. Vienfaktorinè analizė ANOVA skirta keliu gupių vidurkiams palyginti. Vienfaktorinè analizè taikyta skirtingų socialinių grupių lūkesčiams ligoninès atžvilgiu ir ịspūdžiams apie ligoninę palyginti. Norint nustatyti, tarp kurių konkrečiai grupių yra reikšmingi skirtumai, naudota post hoc daugkartinio lyginimo procedūra, Tukey HSD kriterijus. Skirtumai tarp lyginamuju grupiu laikomi statistiškai reikšmingi, kai p<0,05.

Tiriamieji. Tyrime dalyvavo 200 pacientų, 91 (45,5 proc.) vyras ir 109 (54,5 proc.) moterys. Tiriamųjų amžiaus vidurkis - 64,21 m., vyrų $-64,80$ m., moterų $-63,72 \mathrm{~m} .48$ proc. $(\mathrm{n}=96)$ tiriamujų buvo susituokę; daugiau nei pusè ịgiję aukštaji arba aukštesnijji išsilavinimą - atitinkamai 63 (31,5 proc.) ir 57 tiriamieji $(28,5$ proc.); 55 proc. ( $\mathrm{n}=110)$ buvo pensininkai, 65,5 proc. $(\mathrm{n}=131)$ gyveno mieste. 


\section{Tyrimo rezultatai}

Pacientų lūkesčių ligoninès atžvilgiu ịvertinimas. Analizuojant tiriamujų lūkesčius, tarpusavyje lyginti lūkesčiai ligoninès materialinių vertybių, patikimumo, ligoninès darbuotojų jautrumo, pacientų saugumo ir ligoninès darbuotojų empatijos atžvilgiu. Tiriamieji lūkesčius vertino pakankamai aukštais balais - nuo 8 iki maksimalių15 balų. Aukščiausiais balų vidurkiais $(14,39-14,46)$ vertinti materialinių vertybių, ligoninès patikimumo, darbuotojų jautrumo, pacientų saugumo lūkesčiai, kiek mažiau - 13,67 balo vertinti lūkesčiai ligoninès darbuotojų empatijos atžvilgiu (1 lentelè).

Lyginant tiriamujų lūkesčių blokus tarpusavyje statistiškai reikšmingų skirtumų tarp pacientų materialinių vertybių ir patikimumo, ligoninès darbuotojų jautrumo bei pacientų saugumo lūkesčių nenustatyta $(p>0,05)$. Gauti statistiškai reikšmingi skirtumai $(p<0,01)$ tarp lūkesčių ligoninès darbuotojų empatijos atžvilgiu ir kitų blokų, t.y. tiriamųjų lūkesčiai ligoninès darbuotojų empatijos atžvilgiu buvo reikšmingai mažesni (2 lentelè).

Nustatyta, kad moterų lūkesčiai ligoninès materialinių vertybių, patikimumo, ligoninès darbuotojų jautrumo, pacientų saugumo ir ligoninès darbuotojų empatijos atžvilgiu didesni nei vyrų $(\mathrm{p}<0,01)$ (3 lentelè).

Tyrmo metu statistiškai reikšmingų ryšių tarp pacientų lūkesčių ir gyvenamosios vietos nenustatyta. Tiriamujų amžius susijęs tik su lūkesčiais ligoninès darbuotojų empatijos atžvilgiu - didejant amžiui didèjo lūkesčiai $(\mathrm{p}<0,01)$. Taip pat analizuojant duomenis gauta, kad tiriamujų aukštesnis išsilavinimas susijęs su mažesniais lūkesčiais, atitinkamai žemesnis išsilavinimas - su didesniais lūkesčiais. Nustatyti teigiami ryšiai tarp paslaugų kokybès vertinimo ir lūkesčiu ligoninès darbuotojų jautrumo, pacientų saugumo ir ligoninės darbuotojų empatijos atžvilgiu $(\mathrm{p}<0,05)$. Didesni lūkesčiai susiję su geresniais paslaugų ko-

3 lentelè. Pacientų lūkesčių ligoninès atžvilgiu palyginimas priklausomai nuo lyties. $S N$-standartinis nuokrypis, $t$-Stjudento t kriterijus, $p$-reikšmingumo lygmuo

\begin{tabular}{|l|l|l|l|l|l|}
\hline & $\begin{array}{c}\text { Materiali- } \\
\text { nės verty- } \\
\text { bės } \\
\text { vidurkis } \pm \text { SN }\end{array}$ & $\begin{array}{c}\text { Ligoninės } \\
\text { patikimu- } \\
\text { mas } \\
\text { vidurkis } \pm \text { SN }\end{array}$ & $\begin{array}{c}\text { Darbuotoju } \\
\text { jautrumas } \\
\text { vidurkis } \pm \text { SN }\end{array}$ & $\begin{array}{c}\text { Pacientu } \\
\text { saugumas } \\
\text { vidurkis } \pm \text { SN }\end{array}$ & $\begin{array}{c}\text { Darbuotoju } \\
\text { empatija } \\
\text { vidurkis } \pm S N\end{array}$ \\
\hline Vyrai & $14,11 \pm 1,11$ & $14,09 \pm 1,19$ & $14,19 \pm 1,08$ & $14,23 \pm 1,06$ & $13,31 \pm 1,64$ \\
\hline $\begin{array}{l}\text { Mote- } \\
\text { rys }\end{array}$ & $14,63 \pm 0,81$ & $14,63 \pm 0,75$ & $14,68 \pm 0,73$ & $14,61 \pm 0,94$ & $13,96 \pm 1,41$ \\
\hline $\mathrm{t}$ & $-3,840$ & $-3,933$ & $-3,813$ & $-2,718$ & $-3,032$ \\
\hline $\mathrm{p}$ & 0,0001 & 0,0001 & 0,0001 & 0,007 & 0,003 \\
\hline
\end{tabular}

4 lentelè. Respondentų lūkesčių ligoninès atžvilgiu ir jų amžiaus, išsilavinimo, gyvenamosios vietos ir paslaugų kokybès vertinimo sąsajos.

$r$-koreliacijos koeficientas, $p$ - reikšmingumo lygmиo

* reikšmingumo lygmuo $p<0,05$

\begin{tabular}{|l|c|c|c|c|c|}
\hline Lūkesčiai & Amžius & $\begin{array}{c}\text { Išsilavini- } \\
\text { mas }\end{array}$ & $\begin{array}{c}\text { Gyve- } \\
\text { namoji } \\
\text { vieta }\end{array}$ & $\begin{array}{c}\text { Paslaugų } \\
\text { kokybès } \\
\text { vertinimas }\end{array}$ \\
\hline Materialinės vertybės & $\mathrm{r}$ & 0,053 & $-0,180^{*}$ & 0,019 & 0,111 \\
& $\mathrm{p}$ & 0,458 & 0,011 & 0,793 & 0,118 \\
\hline Ligoninės patikimumas & $\mathrm{r}$ & 0,022 & $-0,149^{*}$ & 0,016 & 0,112 \\
& $\mathrm{p}$ & 0,755 & 0,035 & 0,822 & 0,114 \\
\hline Darbuotojų jautrumas & $\mathrm{r}$ & 0,037 & $-0,172^{*}$ & 0,030 & $0,157^{*}$ \\
& $\mathrm{p}$ & 0,607 & 0,015 & 0,670 & 0,026 \\
\hline Pacientų saugumas & $\mathrm{r}$ & 0,112 & $-0,134$ & 0,059 & $0,212^{*}$ \\
& $\mathrm{p}$ & 0,114 & 0,058 & 0,405 & 0,003 \\
\hline Darbuotojų empatija & $\mathrm{r}$ & $0,187^{*}$ & $-0,130$ & 0,122 & $0,356^{*}$ \\
& $\mathrm{p}$ & 0,008 & 0,067 & 0,086 & 0,0001 \\
\hline
\end{tabular}

5 lentelè. Skirtingos socialinès padèties tiriamųjų lūkesčių ligoninės atžvilgiu palyginimas.

$S N$-standartinis nuokrypis, $p$ - reikšmingumo lygmиo

\begin{tabular}{|c|c|c|c|c|c|c|}
\hline \multirow[b]{2}{*}{ Lūkesčiai } & \multicolumn{5}{|c|}{ Socialinė padètis } & \multirow[b]{2}{*}{$\mathbf{p}$} \\
\hline & $\begin{array}{l}\text { Darbininkai } \\
(\mathrm{n}=14) \\
\text { vidurkis } \pm \mathrm{SN}\end{array}$ & $\begin{array}{l}\text { Tarnautojai } \\
(\mathrm{n}=42) \\
\text { vidurkis } \pm \mathrm{SN}\end{array}$ & $\begin{array}{l}\text { Pensininkai } \\
(\mathrm{n}=110) \\
\text { vidurkis } \pm \mathrm{SN}\end{array}$ & $\begin{array}{l}\text { Neigalieji } \\
(\mathrm{n}=24) \\
\text { vidurkis } \pm \mathrm{SN}\end{array}$ & $\begin{array}{l}\text { Bedarbiai } \\
(\mathrm{n}=10) \\
\text { vidurkis } \pm \mathrm{SN}\end{array}$ & \\
\hline $\begin{array}{l}\text { Materialinės } \\
\text { vertybės }\end{array}$ & $14,00 \pm 1,24$ & $14,60 \pm 0,67$ & $14,44 \pm 1,03$ & $14,46 \pm 0,83$ & $13,50 \pm 1,27$ & 0,014 \\
\hline $\begin{array}{l}\text { Ligoninès } \\
\text { patikimumas }\end{array}$ & $14,50 \pm 0,76$ & $14,57 \pm 0,70$ & $14,40 \pm 1,00$ & $14,38 \pm 0,97$ & $13,30 \pm 1,89$ & 0,009 \\
\hline $\begin{array}{l}\text { Darbuotojų } \\
\text { jautrumas }\end{array}$ & $14,64 \pm 0,50$ & $14,57 \pm 0,70$ & $14,45 \pm 1,02$ & $14,50 \pm 0,88$ & $13,70 \pm 1,25$ & 0,101 \\
\hline $\begin{array}{l}\text { Pacientu } \\
\text { saugumas }\end{array}$ & $14,29 \pm 0,91$ & $14,50 \pm 0,99$ & $14,54 \pm 0,96$ & $14,33 \pm 1,01$ & $13,60 \pm 1,43$ & 0,069 \\
\hline $\begin{array}{l}\text { Darbuotojų } \\
\text { empatija }\end{array}$ & $12,93 \pm 2,02$ & $13,55 \pm 1,67$ & $13,83 \pm 1,41$ & $14,08 \pm 1,47$ & $12,40 \pm 1,35$ & 0,010 \\
\hline
\end{tabular}


kybės vertinimais (4 lentelè).

Taikant dispersinę analizę (One-Way ANOVA) įvertinti skirtingos socialinès padèties tiriamujų lūkesčiai ligoninès atžvilgiu. Gauti skirtumai $(\mathrm{p}<0,05)$ tarp skirtingos socialinès padèties tiriamujų grupių lūkesčių materialinių vertybių, ligoninès patikimumo ir darbuotojų empatijos atžvilgiu (5 lentelè).

Išanalizavus tarpgrupinius skirtingos socialinès padèties tiriamujų lūkesčių skirtumus gauta, kad bedarbiai yra ta grupè, kurios lūkesčiai ligoninès atžvilgiu skiriasi nuo kitų grupių $(\mathrm{p}<0,05)$ : bedarbių lūkesčiai materialinių vertybių atžvilgiu yra statistiškai reikšmingi mažesni nei tarnautojų $(\mathrm{p}=0,013)$ ir pensininkų $(\mathrm{p}=0,032)$, ligoninès patikimumo atžvilgiu - statistiškai reišmingai mažesni nei tarnautojų $(\mathrm{p}=0,003)$, pensininkų $(\mathrm{p}=0,008)$, darbininkų $(\mathrm{p}=0,030)$ ir neigaliųjų ( $\mathrm{p}=0,034)$, darbuotojų empatijos atžvilgiu - statistiškai reikšmingai mažesni nei pensininkų $(\mathrm{p}=0,039)$ ir neįgaliujų ( $\mathrm{p}=0,029)$ (6 lentelè).

Pacientų ịspūdžių apie ligoninę įvertinimas. Analizuojant tiriamujjų ịspūdžius apie ligoninę, tarpusavyje palyginami įspūdžiai apie ligoninès materialines vertybes, patikimumą, ligoninès darbuotojų jautrumą, pacientų saugumą ir ligoninès darbuotojų empatiją (7 lentelè). Gauta, kad minimaliausi ịvertinimai (5 balai) pasitaikè patikimumo ir empatijos blokuose, materialinių vertybių bloke buvo minimi geriausi vertinimai - minimalus 7 balai. Didžiausias vidurkis gautas vertinant pacientu saugumą (13,48 balo), mažiausias - vertinant darbuotojų empatiją (12,07 balo).

Taikant Stjudento kriterijų porinėms imtims gauta, kad nèra statistiškai reikšmingų skirtumų $(\mathrm{p}>0,05)$ tik tarp pacientų įspūdžių apie ligoninès darbuotojų jautrumą ir ịspūdžių apie pacientų saugumą, t.y. pacientai vienodai vertina ligoninės darbuotojų jautrumą ir pacientų saugumą (8 lentelè).
6 lentelè. Skirtingos socialinės padèties tiriamųjų lūkesčių materialinių vertybių, ligoninès patikimumo ir darbuotojų empatijos atžvilgiu palyginimas.

$p$-reikšmingumo lygmuo

\begin{tabular}{|c|c|c|c|}
\hline $\begin{array}{l}\text { Lūkes- } \\
\text { čiai }\end{array}$ & \multicolumn{2}{|c|}{ Socialinė padètis } & $\mathbf{p}$ \\
\hline \multirow{5}{*}{ 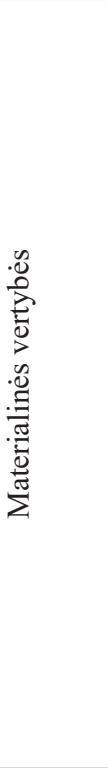 } & $\begin{array}{l}\text { Darbi- } \\
\text { ninkas }\end{array}$ & $\begin{array}{l}\text { Tarnautojas } \\
\text { Pensininkas } \\
\text { Neigalusis } \\
\text { Bedarbis }\end{array}$ & $\begin{array}{l}0,276 \\
0,509 \\
0,626 \\
0,725\end{array}$ \\
\hline & $\begin{array}{l}\text { Tar- } \\
\text { nauto- } \\
\text { jas }\end{array}$ & $\begin{array}{l}\text { Darbininkas } \\
\text { Pensininkas } \\
\text { Neigalusis } \\
\text { Bedarbis }\end{array}$ & $\begin{array}{l}0,276 \\
0,896 \\
0,982 \\
\mathbf{0 , 0 1 3}\end{array}$ \\
\hline & $\begin{array}{l}\text { Pensi- } \\
\text { ninkas }\end{array}$ & $\begin{array}{l}\text { Darbininkas } \\
\text { Tarnautojas } \\
\text { Neigalusis } \\
\text { Bedarbis }\end{array}$ & $\begin{array}{l}0,509 \\
0,896 \\
1,000 \\
\mathbf{0 , 0 3 2}\end{array}$ \\
\hline & $\begin{array}{l}\text { Neiga- } \\
\text { lusis }\end{array}$ & $\begin{array}{l}\text { Darbininkas } \\
\text { Tarnautojas } \\
\text { Pensininkas } \\
\text { Bedarbis }\end{array}$ & $\begin{array}{l}0,626 \\
0,982 \\
1,000 \\
0,070\end{array}$ \\
\hline & $\begin{array}{l}\text { Bedar- } \\
\text { bis }\end{array}$ & $\begin{array}{l}\text { Darbininkas } \\
\text { Tarnautojas } \\
\text { Pensininkas } \\
\text { Neigalusis }\end{array}$ & $\begin{array}{l}0,725 \\
\mathbf{0 , 0 1 3} \\
\mathbf{0 , 0 3 2} \\
0,070\end{array}$ \\
\hline \multirow{3}{*}{ 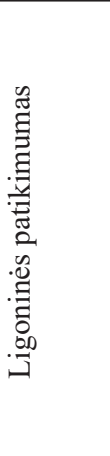 } & $\begin{array}{l}\text { Darbi- } \\
\text { ninkas }\end{array}$ & $\begin{array}{l}\text { Tarnautojas } \\
\text { Pensininkas } \\
\text { Neigalusis } \\
\text { Bedarbis }\end{array}$ & $\begin{array}{l}0,999 \\
0,996 \\
0,996 \\
\mathbf{0 , 0 3 0}\end{array}$ \\
\hline & $\begin{array}{l}\text { Tar- } \\
\text { nauto- } \\
\text { jas }\end{array}$ & $\begin{array}{l}\text { Darbininkas } \\
\text { Pensininkas } \\
\text { Neigalusis } \\
\text { Bedarbis }\end{array}$ & $\begin{array}{l}0,999 \\
0,874 \\
0,937 \\
\mathbf{0 , 0 0 3} \\
\end{array}$ \\
\hline & $\begin{array}{l}\text { Pensi- } \\
\text { ninkas }\end{array}$ & $\begin{array}{l}\text { Darbininkas } \\
\text { Tarnautojas } \\
\text { Neigalusis } \\
\text { Bedarbis }\end{array}$ & $\begin{array}{l}0,996 \\
0,874 \\
1,000 \\
\mathbf{0 , 0 0 8} \\
\end{array}$ \\
\hline
\end{tabular}

\begin{tabular}{|c|c|c|c|}
\hline $\begin{array}{l}\text { Lūkes- } \\
\text { čiai }\end{array}$ & \multicolumn{2}{|c|}{ Socialinė padėtis } & $\mathbf{p}$ \\
\hline \multirow{8}{*}{ 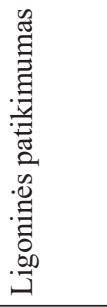 } & Neitga- & Darbininkas & 0,996 \\
\hline & lusis & Tarnautojas & 0,937 \\
\hline & & Pensininkas & 1,000 \\
\hline & & Bedarbis & 0,034 \\
\hline & Bedar- & Darbininkas & $\mathbf{0 , 0 3 0}$ \\
\hline & & Tarnautojas & 0,003 \\
\hline & & Pensininkas & 0,008 \\
\hline & & Neigalusis & 0,034 \\
\hline \multirow{20}{*}{ 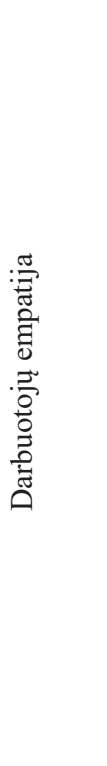 } & Darbi- & Tarnautojas & 0,678 \\
\hline & ninkas & Pensininkas & 0,230 \\
\hline & & Neigalusis & 0,162 \\
\hline & & Bedarbis & 0,917 \\
\hline & & Darbininkas & 0,678 \\
\hline & nauto & Pensininkas & 0,848 \\
\hline & & Neigalusis & 0,642 \\
\hline & & Bedarbis & 0,204 \\
\hline & Pensi- & Darbininkas & 0,230 \\
\hline & ninkas & Tarnautojas & 0,848 \\
\hline & & Neigalusis & 0,945 \\
\hline & & Bedarbis & $\mathbf{0 , 0 3 9}$ \\
\hline & Neiga- & Darbininkas & 0,162 \\
\hline & & Tarnautojas & 0,642 \\
\hline & & Pensininkas & 0,945 \\
\hline & & Bedarbis & 0,029 \\
\hline & Bedar- & Darbininkas & 0,917 \\
\hline & & Tarnautojas & 0,204 \\
\hline & & Pensininkas & $\mathbf{0 , 0 3 9}$ \\
\hline & & Neigalusis & 0,029 \\
\hline
\end{tabular}

7 lentelė. Tiriamujų ịspūdžiai apie ligoninę. SN-standartinis nuokrypis.

\begin{tabular}{|l|l|l|l|}
\hline \multirow{2}{*}{ İspūdžiai } & \multicolumn{3}{|l|}{ İspūdžių vertinimas balais } \\
\cline { 2 - 4 } & Min & Max & vidurkis \pm SN \\
\hline Materialinės vertybės & 7 & 15 & $12,81 \pm 1,90$ \\
\hline Ligoninės patikimumas & 5 & 15 & $12,40 \pm 1,91$ \\
\hline Ligoninès darbuotojų jautrumas & 6 & 15 & $13,38 \pm 2,07$ \\
\hline Pacientų saugumas & 6 & 15 & $13,48 \pm 1,76$ \\
\hline Ligoninės darbuotojų empatija & 5 & 15 & $12,07 \pm 2,16$ \\
\hline
\end{tabular}

Taikant Stjudento kriterijų nepriklausomoms imtims, palyginti vyrų ir moterų įspūdžiai apie ligoninès materialines vertybes, patikimumą, ligoninès darbuotojų jautrumą, pacientų saugumą ir ligoninès darbuotojų empatiją (9 lentelè). Skirtumų tarp vyrų ir moterų įspūdžių apie ligoninę negauta $(\mathrm{p}>0,05)$. 
Nustatant ryšius tarp tiriamuju įspūdžių apie ligoninę ir jų amžiaus, išsilavinimo, gyvenamosios vietos ir paslaugų vertinimo, gauta, kad tiriamujų amžius teigiamai susijęs su visais įspūdžių blokais $(\mathrm{p}<0,05)$ - vyresni respondentai turejjo geresnius ịspūdžius apie ligoninę. Nustatyta, kad aukštesnis išsilavinimas yra susijęs su mažesniais įspūdžiais apie ligoninès materialines vertybes ir ligoninès darbuotojų jautrumą, o žemesnis išsilavinimas - su geresniais įspūdžiais $(\mathrm{p}<0,05)$. Taip pat nustatyti teigiami ryšiai tarp paslaugų kokybės vertinimo ir visų įspūdžių apie ligoninę $(\mathrm{p}<0,05)$. Kuo geresni tiriamujų ịspūdžiai apie ligoninę, tuo aukštesni ir jų ligoninès paslaugų ịvertinimimai. Ryšių tarp pacientų ịspūdžių ir gyvenamosios vietos negavome (10 lentelè).

Taikant dispersinę analizę (OneWay ANOVA) ivvertinti skirtingos socialinès padèties tiriamujų įspūdžiai apie ligoninę. Gauti reikšmingi skirtumai $(p<0,05)$ tarp skirtingos socialinès padèties tiriamuju grupių ịspūdžių apie materialines vertybes, pacientų saugumą ir darbuotojų empatiją (11 lentelè).

Išanalizavus tarpgrupinius skirtingos socialinès padèties tiriamųjų ịspūdžių skirtumus gauta, kad tarnautojai yra ta grupè, kurios įspūdžiai apie ligoninę skiriasi nuo kitų grupių: tarnautojų ispūdžiai apie materialines vertybes yra prastesni nei pensininkų $(\mathrm{p}=0,020)$ ir neigaliujų $(\mathrm{p}=0,019)$, isspūdžiai apie pacientų saugumą mažesni nei pensininkų ( $\mathrm{p}=0,043)$, apie darbuotojų empatiją - mažesni nei neiggaliujų $(p=0,047)$ (12 lentelè).

Vertinant skirtumus tarp pacientu lūkesčių ir įspūdžių nustatyta, kad didžiausias atotrūkis nuo lauktų ir realiai gautų paslaugų buvo susijęs su ligoninės patikimumu $(-1,99)$, darbuotojų empatija $(-1,6)$ bei materialinèmis vertybèmis $(-1,59)$ (13 lentelè).

\section{Rezultatu aptarimas}

Pacientai yra pagrindiniai sveikatos paslaugų kokybès vertintojai, todèl vertinant paslaugų kokybę jų nuomonei teikiama pirmenybe [7].

2013-2015 metais Lenkijos tyrëjai apklausė 416 pacientų, siekdami nustatyti jų pasitenkinimą valstybinių ir privačių sveikatos priežiūros įstaigų teikiamomis paslaugomis [11]. Tyrimo rezultatai parodè, kad ir viešajame, ir privačiajame sektoriuje besigydžiusių pacientų lūkesčiai buvo didesni, nei patirti ịspūdžiai.

8 lentelè. Tiriamųjų ịspūdžių apie ligoninę palyginimas.

vid. sk. - vidurkiu skirtumas, $t$-Stjudento t kriterijus, $p$ - reikšmingumo lygmuo

\begin{tabular}{|l|l|c|c|c|c|}
\hline \multicolumn{2}{|l|}{ Ispūdžiai } & $\begin{array}{c}\text { Ligoninės } \\
\text { patikimu- } \\
\text { mas } \\
\text { (vid=12,40) }\end{array}$ & $\begin{array}{c}\text { Darbuo- } \\
\text { tojų jau- } \\
\text { trumas } \\
\text { (vid=13,38) }\end{array}$ & $\begin{array}{c}\text { Pacientuc } \\
\text { saugumas } \\
\text { (vid=13,48) }\end{array}$ & $\begin{array}{c}\text { Dar- } \\
\text { buotojų } \\
\text { empatija } \\
\text { (vid=12,07) }\end{array}$ \\
\hline Materialinès & vid.sk. & 0,41 & $-0,57$ & $-0,67$ & 0,735 \\
vertybės & $\mathrm{t}$ & 3,431 & $-4,442$ & $-5,598$ & 5,438 \\
(vid=12,81) & $\mathrm{p}$ & 0,001 & 0,0001 & 0,0001 & 0,0001 \\
\hline Ligoninè s & vid.sk. & & $-0,98$ & $-1,08$ & 0,325 \\
patikimumas & $\mathrm{t}$ & & $-8,593$ & $-10,790$ & 2,966 \\
(vid=12,40) & $\mathrm{p}$ & & 0,0001 & 0,0001 & 0,003 \\
\hline Darbuotojų & vid.sk. & & & $-0,10$ & 1,31 \\
jautrumas & $\mathrm{t}$ & & & $-1,071$ & 12,563 \\
(vid=13,38) & $\mathrm{p}$ & & & 0,286 & 0,0001 \\
\hline Pacientų sau- & $\mathrm{vid.sk.}$ & $\mathrm{t}$ & & & 1,41 \\
gumas & & & & 14,490 \\
(vid=13,48) & $\mathrm{p}$ & & & & 0,0001 \\
\hline
\end{tabular}

9 lentelè. Pacientų ịspūdžių apie ligoninę palyginimas priklausomai nuo lyties. $S N$-standartinis nuokrypis, $t$-Stjudento t kriterijus, $p$ - reikšmingumo lygmuo

\begin{tabular}{|l|l|l|l|l|l|}
\hline & $\begin{array}{l}\text { Materialinės } \\
\text { vertybės } \\
\text { vidurkis } \pm \text { SN }\end{array}$ & $\begin{array}{l}\text { Ligonin ė s } \\
\text { patikimumas } \\
\text { vidurkis } \pm \text { SN }\end{array}$ & $\begin{array}{l}\text { Darbuotojų } \\
\text { jautrumas } \\
\text { vidurkis } \pm \text { SN }\end{array}$ & $\begin{array}{l}\text { P a c i e n t ụ } \\
\text { saugumas } \\
\text { vidurkis } \pm \text { SN }\end{array}$ & $\begin{array}{l}\text { Darbuotoju } \\
\text { empatija } \\
\text { vidurkis } \pm \text { SN }\end{array}$ \\
\hline Vyrai & $12,74 \pm 1,90$ & $12,22 \pm 2,12$ & $13,16 \pm 2,26$ & $13,24 \pm 1,91$ & $11,80 \pm 2,28$ \\
\hline Moterys & $12,86 \pm 1,91$ & $12,54 \pm 1,72$ & $13,56 \pm 1,89$ & $13,67 \pm 1,61$ & $12,29 \pm 2,04$ \\
\hline $\mathrm{t}$ & $-0,466$ & $-1,185$ & $-1,346$ & $-1,722$ & $-1,608$ \\
\hline $\mathrm{p}$ & 0,642 & 0,237 & 0,180 & 0,087 & 0,109 \\
\hline
\end{tabular}

10 lentelè. Ryšiai tarp tiriamųjų įspūdžių apie ligoninę ir tiriamųjų amžiaus, išsilavinimo, gyvenamosios vietos ir paslaugų kokybès vertinimo.

$r$ - koreliacijos koeficientas, $p$ - reikšmingumo lygmuo

* reikšmingumo lygmuo $p<0,05$

\begin{tabular}{|l|c|c|c|c|c|}
\hline Ispūdžiai & Amžius & $\begin{array}{c}\text { Išsilavi- } \\
\text { nimas }\end{array}$ & $\begin{array}{c}\text { Gyve- } \\
\text { namoji } \\
\text { vieta }\end{array}$ & $\begin{array}{c}\text { Paslaugu } \\
\text { kokybe்s } \\
\text { vertinimas }\end{array}$ \\
\hline Materialinės vertybės & $\mathrm{r}$ & $0,218^{*}$ & $-0,209^{*}$ & $-0,105$ & $0,377^{*}$ \\
& $\mathrm{p}$ & 0,002 & 0,003 & 0,140 & 0,000 \\
\hline Ligoninès patikimumas & $\mathrm{r}$ & $0,177^{*}$ & $-0,082$ & $-0,035$ & $0,515^{*}$ \\
& $\mathrm{p}$ & 0,012 & 0,250 & 0,624 & 0,000 \\
\hline Darbuotojų jautrumas & $\mathrm{r}$ & $0,234^{*}$ & $-0,125$ & $-0,057$ & $0,620^{*}$ \\
& $\mathrm{p}$ & 0,001 & 0,078 & 0,423 & 0,000 \\
\hline Pacientų saugumas & $\mathrm{r}$ & $0,263^{*}$ & $-0,105$ & $-0,004$ & $0,631^{*}$ \\
& $\mathrm{p}$ & 0,0001 & 0,139 & 0,959 & 0,000 \\
\hline Darbuotojų empatija & $\mathrm{r}$ & $0,190^{*}$ & $-0,161 *$ & $-0,010$ & $0,589^{*}$ \\
& $\mathrm{p}$ & 0,007 & 0,023 & 0,886 & 0,000 \\
\hline
\end{tabular}


İdomu tai, kad pacientų lūkesčiai valstybinès sveikatos priežiūros įstaigos atžvilgiu buvo didesni nei privačios. Nepaisant to, privačiose ligoninèse gydyti pacientai mažiau nusivylè paslaugų kokybe ir bendras ịspūdžių ịvertinimas buvo didesnis, palyginti su valstybinėmis ịstaigomis. Tai reiškia, kad privačių ligoninių pacientai nesitikejo tokio aukšto paslaugų lygio kaip viešųų ịstaigų pacientai, tačiau gavo aukštesnio lygmens paslaugas nei pastarieji. Viešųų įstaigų pacientai labiausiai nusivylè ligoninès materialinèmis vertybèmis (atotrūkis - -2,2) ir patikimumu (atotrūkis - -2,0) $(\mathrm{p}<0,001)$, tuo tarpu kai privačių įstaigų pacientai labai neišskyrè nepasitenkinimo viena ar kita sritimi - bendras įspūdžių įvertinimas visose blokuose buvo labai panašus (atotrūkis tarp lūkesčių ir įspūdžių sudare nuo $-0,8$ iki $-0,5(p<0,001)$. Mūsų tyrime nenagrinèjome skirtumų tarp viešojo ir privataus sektoriaus, tačiau kalbant tik apie viešąji sektorių, didžiausią atotrūkị gavome tarp ligoninès patikimumo lūkesčių ir ịspūdžių $(-1,99)$, ir tai sutampa su Lenkijos tyrejjų gautais rezultatais. Mažiausias atotrūkis mūsų ir Lenkijos mokslininkų tyrime taip pat sutampa - jis nustatytas tarp saugumo lūkesčių ir įspūdžių (mūsų - -0,96; Lenkijos tyrèjų - -0,7).

11 lentelè. Skirtingos socialinès padėties tiriamųjų įspūdžių ligoninės atžvilgiu palyginimas. $S N$-standartinis nuokrypis, $p$ - reikšmingumo lygmuo

\begin{tabular}{|c|c|c|c|c|c|c|}
\hline \multirow[b]{2}{*}{ İspūdžiai } & \multicolumn{5}{|c|}{ Socialinė padėtis } & \multirow[b]{2}{*}{$\mathbf{p}$} \\
\hline & $\begin{array}{l}\text { Darbininkai } \\
(\mathrm{n}=14) \\
\text { vidurkis } \pm \mathrm{SN}\end{array}$ & $\begin{array}{c}\text { Tarnautojai } \\
(\mathrm{n}=42) \\
\text { vidurkis } \pm \mathrm{SN}\end{array}$ & $\begin{array}{c}\text { Pensininkai } \\
(\mathrm{n}=110) \\
\text { vidurkis } \pm \mathrm{SN}\end{array}$ & $\begin{array}{c}\text { Neigalieji } \\
(\mathrm{n}=24) \\
\text { vidurkis } \pm \text { SN }\end{array}$ & $\begin{array}{c}\text { Bedarbiai } \\
(\mathrm{n}=10) \\
\text { vidurkis } \pm \mathrm{SN}\end{array}$ & \\
\hline $\begin{array}{l}\text { Materialinès } \\
\text { vertybės }\end{array}$ & $13,14 \pm 1,56$ & $12,00 \pm 2,29$ & $13,03 \pm 1,72$ & $13,46 \pm 1,44$ & $11,70 \pm 2,21$ & 0,003 \\
\hline $\begin{array}{l}\text { Ligoninès } \\
\text { patikimumas }\end{array}$ & $12,71 \pm 1,49$ & $11,95 \pm 2,19$ & $12,51 \pm 1,70$ & $12,96 \pm 2,05$ & $11,20 \pm 2,57$ & 0,059 \\
\hline $\begin{array}{l}\text { Darbuotoju } \\
\text { jautrumas }\end{array}$ & $13,14 \pm 1,35$ & $12,90 \pm 2,47$ & $13,57 \pm 1,98$ & $13,96 \pm 1,68$ & $12,20 \pm 2,30$ & 0,074 \\
\hline $\begin{array}{l}\text { Pacientų } \\
\text { saugumas }\end{array}$ & $13,00 \pm 1,84$ & $12,93 \pm 1,77$ & $13,73 \pm 1,67$ & $13,96 \pm 1,52$ & $12,50 \pm 2,32$ & 0,014 \\
\hline $\begin{array}{l}\text { Darbuotojų } \\
\text { empatija }\end{array}$ & $12,29 \pm 2,20$ & $11,29 \pm 2,25$ & $12,27 \pm 1,99$ & $12,79 \pm 2,06$ & $11,10 \pm 2,89$ & 0,022 \\
\hline
\end{tabular}

2017 m. Turkijos tyrèjai vertino sveikatos priežiūros paslaugų kokybę Pakistane. Apklausoje dalyvavo 246 pacientai, kurių buvo prašoma nurodyti jų lūkesčius ir ìspūdžius, susijusius su materialinėmis vertybėmis, pacientų saugumu, ligoninès patikimumu, darbuotoju jautrumu ir empatija Aybo mokymo ligonineje [12]. Tyrèjai nustatè, kad pacientų lūkesčiai viršijo patirtus įspūdžius. Labiausiai pacientus nuvylè materialinès vertybès, pacientų saugumas ir ligoninès patikimumas, tačiau pacientai liko patenkinti darbuotojų jautrumu ir empatija. Mūsų tyrimas taip pat parodé, kad pacientų lūkesčiai buvo didesni nei ìspūdžiai $(p<0,05)$. Turkijos tyrẻjų nuomone, jų rezultatai atspindi tik tam tikros ligoninès pacientu nuomonę, todèl jų negalima laikyti reprezentatyviais visam regionui. Gauti rezultatai rodo, kad sveikatos priežiūros įstaigų vadovai turi daugiau dèmesio skirti pacientų pasitenkinimui materialinèmis vertybėmis ir ligoninės patikimumu bei atsižvelgti ị būtinumą vertinti

\begin{tabular}{|c|c|c|c|}
\hline $\begin{array}{l}\text { Ispū- } \\
\text { džiai }\end{array}$ & \multicolumn{2}{|c|}{ Socialinė padètis } & \multirow{2}{*}{$\begin{array}{l}\mathbf{p} \\
0,266 \\
0,999 \\
0,986 \\
0,326\end{array}$} \\
\hline \multirow{5}{*}{$\begin{array}{l}\text { Mate- } \\
\text { rialinės } \\
\text { verty- } \\
\text { bės }\end{array}$} & Darbininkas & $\begin{array}{l}\text { Tarnautojas } \\
\text { Pensininkas } \\
\text { Neigalusis } \\
\text { Bedarbis }\end{array}$ & \\
\hline & Tarnautojas & $\begin{array}{l}\text { Darbininkas } \\
\text { Pensininkas } \\
\text { Neigalusis } \\
\text { Bedarbis }\end{array}$ & $\begin{array}{l}0,266 \\
\mathbf{0 , 0 2 0} \\
\mathbf{0 , 0 1 9} \\
0,991\end{array}$ \\
\hline & Pensininkas & $\begin{array}{l}\text { Darbininkas } \\
\text { Tarnautojas } \\
\text { Neigalusis } \\
\text { Bedarbis }\end{array}$ & $\begin{array}{l}0,999 \\
\mathbf{0 , 0 2 0} \\
0,837 \\
0,192 \\
\end{array}$ \\
\hline & Neigalusis & $\begin{array}{l}\text { Darbininkas } \\
\text { Tarnautojas } \\
\text { Pensininkas } \\
\text { Bedarbis }\end{array}$ & $\begin{array}{l}0,986 \\
\mathbf{0 , 0 1 9} \\
0,837 \\
0,087 \\
\end{array}$ \\
\hline & Bedarbis & $\begin{array}{l}\text { Darbininkas } \\
\text { Tarnautojas } \\
\text { Pensininkas } \\
\text { Neigalusis }\end{array}$ & $\begin{array}{l}0,326 \\
0,991 \\
0,192 \\
0,087\end{array}$ \\
\hline
\end{tabular}

12 lentelè. Skirtingos socialinės padèties tiriamųjų ịspūdžių materialinių vertybių, ligoninès patikimumo ir darbuotojų empatijos atžvilgiu palyginimas. $p$-reikšmingumo lygmuo

\begin{tabular}{|c|c|c|c|}
\hline \multirow{5}{*}{$\begin{array}{l}\text { Pacienty } \\
\text { saugu- } \\
\text { mas }\end{array}$} & Darbininkas & $\begin{array}{l}\text { Tarnautojas } \\
\text { Pensininkas } \\
\text { Neigalusis } \\
\text { Bedarbis }\end{array}$ & $\begin{array}{l}1,000 \\
0,571 \\
0,464 \\
0,956\end{array}$ \\
\hline & Tarnautojas & $\begin{array}{l}\text { Darbininkas } \\
\text { Pensininkas } \\
\text { Neigalusis } \\
\text { Bedarbis }\end{array}$ & $\begin{array}{l}1,000 \\
\mathbf{0 , 0 4 3} \\
0,138 \\
0,955 \\
\end{array}$ \\
\hline & Pensininkas & $\begin{array}{l}\text { Darbininkas } \\
\text { Tarnautojas } \\
\text { Neigalusis } \\
\text { Bedarbis } \\
\end{array}$ & $\begin{array}{l}0,571 \\
\mathbf{0 , 0 4 3} \\
0,976 \\
0,200 \\
\end{array}$ \\
\hline & Neigalusis & $\begin{array}{l}\text { Darbininkas } \\
\text { Tarnautojas } \\
\text { Pensininkas } \\
\text { Bedarbis }\end{array}$ & $\begin{array}{l}0,464 \\
0,138 \\
0,976 \\
0,166 \\
\end{array}$ \\
\hline & Bedarbis & $\begin{array}{l}\text { Darbininkas } \\
\text { Tarnautojas } \\
\text { Pensininkas } \\
\text { Neigalusis }\end{array}$ & $\begin{array}{l}0,956 \\
0,955 \\
0,200 \\
0,166\end{array}$ \\
\hline
\end{tabular}

\begin{tabular}{|c|c|c|c|}
\hline \multirow{5}{*}{$\begin{array}{l}\text { Dar- } \\
\text { buo- } \\
\text { tojų } \\
\text { empa- } \\
\text { tija }\end{array}$} & Darbininkas & $\begin{array}{l}\text { Tarnautojas } \\
\text { Pensininkas } \\
\text { Neigalusis } \\
\text { Bedarbis }\end{array}$ & $\begin{array}{l}0,545 \\
1,000 \\
0,954 \\
0,660\end{array}$ \\
\hline & Tarnautojas & $\begin{array}{l}\text { Darbininkas } \\
\text { Pensininkas } \\
\text { Neigalusis } \\
\text { Bedarbis }\end{array}$ & $\begin{array}{l}0,545 \\
0,081 \\
\mathbf{0 , 0 4 7} \\
0,999 \\
\end{array}$ \\
\hline & Pensininkas & $\begin{array}{l}\text { Darbininkas } \\
\text { Tarnautojas } \\
\text { Neigalusis } \\
\text { Bedarbis }\end{array}$ & $\begin{array}{l}1,000 \\
0,081 \\
0,813 \\
0,452 \\
\end{array}$ \\
\hline & Neigalusis & $\begin{array}{l}\text { Darbininkas } \\
\text { Tarnautojas } \\
\text { Pensininkas } \\
\text { Bedarbis }\end{array}$ & $\begin{array}{l}0,954 \\
\mathbf{0 , 0 4 7} \\
0,813 \\
0,216\end{array}$ \\
\hline & Bedarbis & $\begin{array}{l}\text { Darbininkas } \\
\text { Tarnautojas } \\
\text { Pensininkas } \\
\text { Neiggalusis }\end{array}$ & $\begin{array}{l}0,660 \\
0,999 \\
0,452 \\
0,216\end{array}$ \\
\hline
\end{tabular}


pacientų nuomonę apie jų teikiamas paslaugas, siekiant pagerinti teikiamų paslaugų kokybę.

Platesnį tyrimą, leidžiantị plačiai apžvelgti situaciją Rytų valstybėse 2017 m. atliko Irano mokslininkai [13]. Naudodamiesi Web of Sciences, PubMed, Scopus, Google Scholar, Magiran, Iran Medex ir Scientific Information Database duomenų bazèmis, jie išnagrinèjo 115 mokslinių publikacijų, paskelbtų 2009-2016 metais ir susijusių su pacientų lūkesčiais ir ịspūdžiais bei jų skirtumu. Po detalaus publikacijų ịvertinimo tyrejai išrinko 12 , kurių duomenis lygino tarpusavyje. Straipsnyje buvo palyginti pacientų lūkesčių ir ịspūdžių vidurkių skirtumai penkiose srityse. Didžiausias atotrūkis tarp pacientų lūkesčių ir ịspūdžių buvo susijęs su pacientų nuomone apie ligoninés patikimumą ir darbuotojų jautrumą $(-1,22$ ir $-1,15)(\mathrm{p}<0,001)$. Tyrejai nurodo, kad nepakankamas reagavimas ị šias sritis kelia grèsmę ịstaigų reputacijai, todèl personalo mokymo organizavimas šiose ịstaigose turi tapti prioritetu. Nepasitenkinimas teikiamomis paslaugomis rodo nepakankamą dèmesį, kuris yra skiriamas pacientų teisèms. Tiesioginis bendravimas su pacientais ir laiku suteiktos paslaugos gali sumažinti jų nepasitenkinimą [14]. Mažiausias skirtumas tarp lūkesčių ir gautų paslaugų buvo susijęs su darbuotojų empatija $(-1,03)$ ir ligoninès materialinèmis vertybėmis $(-1.03)(\mathrm{p}<0,001)$. Mokslininku nuomone, sveikatos priežiūros įstaigų vadovai suvokia šių sričių svarbą ir stengiasi aprūpinti darbuotojus reikiama įranga bei rūpinasi personalo ịvaizdžiu. Be to, tokius rezultatus galima paaiškinti Rytų valstybėse gyvenančių žmonių bendravimo specifika. Taip pat šio tyrimo rezultatai atskleidè, kad vyrų paslaugų vertinimo vidurkių skirtumas $(-1,29)$ yra mažesnis nei moterų $(-1,80)(\mathrm{p}=0,005)$. Mūsų tyrimo rezultatai taip pat rodo, kad vyrų lūkesčiai materialinių vertybių, ligoninès patikimumo, darbuotojų jautrumo, pacientų saugumo ir darbuotojų empatijos atžvilgiu buvo mažesni nei moterų $(\mathrm{p}<0,05)$. Galima daryti prielaidą, kad moterys tikisi geresnių sveikatos priežiūros paslaugų nei vyrai, todèl dažniau yra nepatenkintos suteiktomis paslaugomis.

Žaneta Piligrimienè ir kt. (2010) išnagrinejjo sveikatos priežiūros paslaugų kokybę įstaigos vadovybès ir persnalo požiūriu [15]. Tyrime dalyvavo 5 ligonèse dirbantys 75 administracijos atstovai ir 318 medikų, kuriems buvo pateiktas vienodas klausimynas su 72 klausimais, atspindinčiais jų požiūrị i 13 paslaugų kokybės dimensijų. Tyrimo rezultatai parodè, kad svarbiausi sveikatos priežiūros specialistų ir sveikatos priežiūros organizacijų vadovybės kokybės aspektai yra siejami su technine baze. Mūsų tyrimas parodè, kad kardiologijos centre besigydę pacientai taip pat aukštai vertino savo lūkesčius ligoninès materialinių vertybių atžvilgiu (vidurkis 14,40). Nors Ž. Piligrimienès ir bendraautorių atliktas tyrimas parodè, jog vadybininkai laiko ligoninèje naudojamą įrangą svarbesne nei tos ligoninès reputacija ir patikimumas pacientų požiūriu, po 8 metu pacientai lieka nepatenkinti ir ligoninès patikimumu, ir materialinėmis vertybėmis. Mūsų tyrime lūkesčių ir ịspūdžių vidurkio skirtumai, susiję su materialinèmis vertybėmis $(-1,56)$ ir ligoninès patikimumu $(-1,99)$, buvo didžiausi nei kitų sričių. Galima daryti prielaidą, kad pacientų nepasitenkinimas ligoninès patikimumu atsiranda dèl sveikatos priežiūros ịstaigu vadovybės požiūrio ị ligoninès patikimumo svarbą ir dedamų pastangų tam patikimumui užtikrinti. Nepaisant to įstaigų vadovai supranta, kad pacientai visada tikisi, kad jų sveikata bus rūpinamasi, naudojantis pažangiausia diagnostikos ir gydymo įranga, kuri yra prieinama šiuo metu.

Bakento universitete atsitiktinès atrankos būdu apklausti ịvairių ligoninių pacientai. Jaunesni pacientai pažymi didesnị atotrūkị tarp paslaugu kokybės lūkesčių bei realiai patirtos paslaugų kokybès. Labiau išsilavinusių žmonių paslaugų kokybès lūkesčiai didesni nei turinčių mažesni išsilavinimą. Mokslininkų išvadose buvo pažymèta, kad panašiuose tyrimuose pacientų pasitenkinimas paslaugomis visuomet yra gana didelis ir sunku apibrèžti tobulintinas sritis, todèl ligoninių paslaugų kokybės vertinimui reikalingas jautresnis instrumentas, gebantis užfiksuoti pokyčius [16]. Mes savo tyrime nenagrinėjome, kokị atotrūkị tarp lūkesčių ir įspūdžių pažymi skirtingo amžiaus pacientai, bet, skirtingai nuo Bakento universiteto atlikto tyrimo, nustatème, kad išsilavinimas statistiškai reikšmingai neigiamai susijęs su lūkesčiais, t.y. aukštesnis išsilavinimas susijęs su mažesniais lūkesčiais, atitinkamai žemesnis išsilavinimas - su didesniais lūkesčiais.

Korejos Cheju nacionalinio universiteto slaugos skyriaus medicinos mokykloje buvo matuojamas skirtumas tarp pacientų ir slaugytojų lūkesčiu ir ịspūdžių bei pasitenkinimo paslaugomis. Lūkesčių skalëje svarbiausiu faktoriumi tapo jautrumas, o įspūdžiu - saugumas. Rasta teigiama koreliacija tarp lūkesčiu bei įspūdžių skalių ir pasitenkinimo slauga. Prieita išvada, kad slaugos kokybė reikšmingai susijusi su ịspūdžių skale [17].

13 lentelè. Tiriamųjų lūkesčių ir įspūdžių vidurkių skirtumai. $S N-$ standartinis nuokrypis, ${ }^{*} p<0,05$

\begin{tabular}{|l|c|c|c|}
\hline Vertinamos sritys & $\begin{array}{c}\text { Lūkesčiai } \\
\text { vidurkis } \pm \text { SN }\end{array}$ & $\begin{array}{c}\text { Ispūdžiai } \\
\text { vidurkis } \pm S N\end{array}$ & $\begin{array}{c}\text { Skirtu- } \\
\text { mas }\end{array}$ \\
\hline Materialinės vertybės & $14,40 \pm 0,99$ & $12,81 \pm 1,90$ & $-1,59^{*}$ \\
\hline Ligoninės patikimumas & $14,39 \pm 1,01$ & $12,40 \pm 1,91$ & $-1,99^{*}$ \\
\hline Ligoninės darbuotojų jautrumas & $14,46 \pm 0,94$ & $13,38 \pm 2,07$ & $-1,08^{*}$ \\
\hline Pacientų saugumas & $14,44 \pm 1,01$ & $13,48 \pm 1,76$ & $-0,96^{*}$ \\
\hline Ligoninės darbuotojų empatija & $13,67 \pm 1,55$ & $12,07 \pm 2,16$ & $-1,6^{*}$ \\
\hline
\end{tabular}


Mūsų atliktame tyrime taip pat jautrumo lūkesčiai vertinti aukščiausiu balu - 14,46, o iš ịspūdžių aukščiausiai vertintas saugumas - 13,48. Taip pat gautos teigiamos koreliacijos tarp paslaugų vertinimų ir visu įspūdžių apie ligoninę bei tarp tiriamujjų lūkesčiu ir ịspūdžių - kuo didesni lūkesčiai, tuo geresni įspūdžiai; kuo geresni įspūdžiai, tuo palankiau vertinamos paslaugos $(\mathrm{p}<0,01)$.

Kitų autorių atliktų tyrimų duomenimis, dauguma tiriamujjų kaip reikšmingiausią kokybiškos paslaugos rodiklị nurodo empatiją [18]. Mūsų tyrime lūkesčiai ir įspūdžiai darbuotojų empatijos atžvilgiu buvo vertinami prasčiausiai iš visų blokų - atitinkamai 13,67 ir 12,07 balo. Tai rodo, kad tiriamujų lūkesčiai empatijos atžvilgiu yra mažiausi, didelès darbuotojų empatijos pacientai nesitiki. İspūdžiai apie empatiją taip pat prasčiausi - tai rodo, kad tai labiausiai tobulintina paslaugų sritis.

Ispanijoje, Malagoje, Karoso Hajos universitetinèje ligoninejje atliktas tyrimas parodè, kad kriterijai, kurie reikšmingai susiję su mažesniu pacientų pasitenkinimu slaugos kokybe yra moteriška lytis bei aukštesnis išsilavinimas [19]. Mūsų tyrime negauta skirtumų tarp vyrų ir moterų ịspūdžių apie ligoninę ( $>00,05)$. $O$ išsilavinimas statistiškai reikšmingai neigiamai susijęs su įspūdžiais apie materialines vertybes ir darbuotojų jautrumą, t.y. aukštesnis išsilavinimas susijęs su prastesniais įspūdžiais, atitinkamai žemesnis išsilavinimas - su geresniais įspūdžiais. Nustatyti statistiškai reikšmingi teigiami ryšiai tarp paslaugų kokybès vertinimo ir ịspūdžių apie ligoninę. Kuo geresni tiriamujų ịspūdžiai apie ligoninę, tuo aukštesni paslaugų ịvertinimai.

Irano Kermano universitete atsitiktinai parinktose ligoninèse atlikto skerspjūvio tyrimo metu buvo užfiksuotas toks skirtumas tarp pacientų lūkesčių ir įspūdžių: saugumas $-1,28$, empatija $-1,36$, jautrumas $-1,80$, materialinès vertybès $-1,86$, patikimumas $-1,69$. Porinis Stjudento kriterijus parodè, kad skirtumas tarp pacientų lūkesčių ir ịspūdžių yra reikšmingas $(p<0,05)$. Buvo nustatyta, kad tirtos ligoninès nebuvo pasiruošusios suteikti pacientų lūkesčius atitinkančių paslaugų [20]. Mūsų tyrime gauti geresni rezultatai - nors pacientų íspūdžiai taip pat buvo statistiškai reikšmingai mažesni už lūkesčius, vis tik ir įspūdžiai vertinti aukštais balais. Didžiausias atotrūkis gautas tarp patikimumo lūkesčių ir ịspūdžių $(1,99)$. Tuo tarpu Kermano universitete didžiausias skirtumas buvo tarp materialinių vertybių lūkesčių ir įspūdžių $(1,86)$. Mažiausias atotrūkis mūsų ir Irano tyrime sutampa - jis nustatytas tarp saugumo lūkesčių ir įspūdžių (mūsų 0,96; Irane 1,28). Kitų blokų skirtumai mūsų tyrime buvo: darbuotojų empatijos - 1,6; materialinių vertybių - 1,59; darbuotojų jautrumo - 1,08. Matome, kad patikimumo ir empatijos atotrūkiai didesni pas mus, o materialinių vertybių, pacientų saugumo ir dar- buotojų jautrumo skirtumai didesni Kermano universitete atliktame tyrime.

\section{Išvados}

1. Tiriamieji aukštais balais vertino lūkesčius ligoninès atžvilgiu. Vyrų lūkesčiai materialinių vertybių, ligoninès patikimumo, darbuotojų jautrumo, pacientų saugumo ir darbuotojų empatijos atžvilgiu buvo mažesni nei moterų. Apklaustujų amžius reikšmingai teigiamai susijęs su lūkesčiais darbuotojų empatijos atžvilgiu. Aukštesnis išsilavinimas susijęs su mažesniais lūkesčiais ligoninès materialinių vertybių, patikimumo ir darbuotojų jautrumo atžvilgiu.

2. Nustatyti vienodai geri pacientų įspūdžiai apie ligoninès darbuotojų jautrumą ir pacientų saugumą, blogesni ịspūdžiai - apie ligoninès materialines vertybes, patikimumą ir darbuotojų empatiją. Tiriamujų amžius reikšmingai teigiamai susijęs su visais ịspūdžiais apie ligoninę. Aukštesnis išsilavinimas susijęs su prastesniais įspūdžiais apie materialines vertybes ir ligoninès darbuotojų jautrumą.

3. Tyrimo dalyvių lūkesčiai buvo didesni nei ịspūdžiai. Nustatytos reikšmingos koreliacijos tarp tiriamujų lūkesčių ligoninès atžvilgiu ir įspūdžių apie ligoninę.

\section{Literatūra}

1. Lietuvos Respublikos sveikatos apsaugos ministerija. Issakymas Nr. V-82, 2017-01-31, "Dẻl Lietuvos Respublikos sveikatos apsaugos ministerijos 2017-2019 metų strateginio veiklos plano patvirtinimo". Prieiga per internetą: https://sam.lrv.lt/ uploads/sam/documents/files/Administracine_informacija/ Planavimo_dokumentai/Strateginiai_veiklos_planai/20172019/1_V-82.pdf.

2. Resolution A/RES/70/1. Transforming our world: the 2030 agenda for sustainable development. In: Seventieth United Nations General Assembly, New York, 25 September 2015. New York: United Nations; 2015. Prieiga per internetą: http://www.un.org/ga/search/view_doc.asp?symbol=A/ RES/70/1\&Lang=E.

3. Akachi Y, Kruk ME. Quality of care: measuring a neglected driver of improved health. Bull World Health Organ 2017; 95(6):465-472.

https://doi.org/10.2471/BLT.16.180190

4. Viešosios įstaigos Šiaulių centro poliklinikos 2017 metų veiklos ataskaita. 2018. Prieiga per internetą http://siauliupoliklinika. 1t/siuntiniai/veiklos_ataskaita_2017.pdf.

5. Viešosios įstaigos Neringos pirminès sveikatos priežiūros vadovo 2017 metų ataskaita. 2018.

Prieiga per internetą: https://www.neringospspc.lt/wp-content/ uploads $/ 2017 / 11 / \mathrm{V} \% \mathrm{C} 5 \% \mathrm{~A} 1 \% \mathrm{C} 4 \% \mathrm{AE}-N$ ringos-PSPC-vadovo-2017-met $\%$ C5\%B3-ataskaita.pdf.

6. Vasiliauskas A. Vš ̇ Alytaus apskrities S. Kudirkos ligoninès vadovo veiklos programa, 2017. Prieiga per internetą: http:// www.ligonine.lt/userfiles/file/VadovoVeiklosPrograma.pdf 
7. Lietuvos Respublikos sveikatos apsaugos ministerija. Isakymas Nr. V-1292, 2017-11-15, "Dèl Asmens sveikatos priežiūros paslaugų kokybės gerinimo programos patvirtinimo". Prieiga per internetą: https://e-seimas.lrs.lt/portal/legalAct/lt/TAD/3c a52110caac11e782d4fd2c44cc67af/CcdbSnkOMc.

8. Poškutė V, Bivainienė L. AB "Šiaulių bankas" paslaugų kokybès vertinimas. Ekonomika ir vadyba: aktualijos ir perspektyvos, 2011; 3(23):55-64.

9. Nejadjavad M, Gilaninia S. The role of service quality in organizations. Kuwait Chapter of Arabian Journal of Business and Management Review 2016; 5(7):19-26.

https://doi.org/10.12816/0019403

10. World Health Organisation. Health is a fundamental human right. Statement by Dr Tedros Adhanom Ghebreyesus (WHO Director-General), 10 December 2017. Prieiga per internetą: http://www.who.int/mediacentre/news/statements/fundamental-human-right/en/.

11. Manulik S, Rosinczuk J, Karniej P. Evaluation of health care service quality in Poland with the use of SERVQUAL method at the specialist ambulatory health care center. Patient Preference and Adherence 2016; 10:1435-1442.

https://doi.org/10.2147/PPA.S108252

12. Ali M. How patients perceive health care services: A case of Ayub Teaching Hospital, Abbottabad - Pakistan. SERV Service QUAL Quality. International Journal of Health care Management 2018; 11(1):52-59.

https://doi.org/10.1080/20479700.2017.1304324

13. Teshnizi SH, Aghamolaei T, Kahnouji K, Teshnizi SMH, Ghani J. Assessing quality of health services with the SERVQUAL Model in Iran. A systematic review and metaanalysis. International Journal for Quality in Health Care 2018; 30(2):82-89. https://doi.org/10.1093/intqhc/mzx200

14. Torabipour A, Sayaf R, Salehi R. et al. Analyzing the quality gapsin the services of rehabilitation centers using the SERVQUAL Technique in Ahvaz, Iran. Jundishapur J Health Sci 2016;8:25-30.

https://doi.org/10.17795/jjhs-32560

15. Piligrimiené Ž. Health care organization service quality: interdisciplinary approach. Summary of doctoral dissertation. Kaunas. Technologija, 2010.

16. Bakar C, Akgün HS, Al Assaf AF. The role of expectations in patients' hospital assessments: a Turkish University Hospital Example. Int J Health Care Qual Assur 2008; 21(5):503.-16p.

17. Kim JH, Lee IS. The differences in quality perceptions, expectations, evaluation, and satisfaction for nursing service between patients and nurses: small medium Sized General Hospitals. Taehan Kanho Hakhoe Chi 2004; 34(7):1243-54.
18. Chou SM, Chen TF, Woodard B, Yen MF. Using SERVQUAL to evaluate quality disconfirmation of nursing service in Taiwan. J Nurs Res 2005; 13(2):75-84. https://doi.org/10.1097/01.JNR.0000387529.22642.2b

19. González-Valentín A, Padín-López S, de Ramón-Garrido E. Patient satisfaction with nursing care in a regional university hospital in Southern Spain. J Nurs Care Qual 2005; 20(1):6372.

https://doi.org/10.1097/00001786-200501000-00011

20. Nekoei-Moghadam M, Amiresmaili M. Hospital services quality assessment: hospitals of Kerman university of medical sciences, as a tangible example of a developing country. Int $\mathrm{J}$ Health Care Qual Assur 2011; 24(1):57-66.

https://doi.org/10.1108/09526861111098247

\section{HEALTH CARE QUALITY ASSESSMENT IN CARDIOLOGY CENTER: VIEWPOINT OF PATIENTS \\ A.Mikaliūkštienė, L.Baltokaitė, D.Kalibatienė, N.Jerdiakova}

Key words: health service quality, service quality assessment, patient expectations, patient feedback.

Summary

The aim of the work: to analyse health service quality from the viewpoint of patients in the Cardiology Center of the Vilnius Hospital.

Materials and Methods. The accomplished survey involved 200 patients interviewed. The patients' expectations and impressions about the health care provided at the Cardiology Center of the Vilnius hospital were evaluated.

Data analysis was performed applying the statistical computer program SPSS13.0 and Microsoft Office Excel 2007.

Results and conclusions. The patients assessed their expectations in relation with the hospital concerned in high scores. The male patients' expectations on the hospital tangible assets, reliability of the hospital, staff sensitivity, patients' safety and staff empathy was statistically significantly lower than expectations of the female patients $(p<0,05)$. The age of the patients interviewed significantly positively was related with patients' expectations with regard to the hospital staff empathy. Higher education of the patients was associated with lower expectations towards the hospital tangible assets, its reliability and staff sensitivity. The patients interviewed had higher expectations than their final feedback $(\mathrm{p}=0.0001)$. The significant $(\mathrm{p}<0,01)$ correlation between the patients' expectations with regard to the hospital and their feedback was identified.

Correspondence to: aldona.mikaliukstiene@mf.vu.lt

Gauta 2018-10-08 